\title{
Ways of dying: AIDS care and agency in contemporary urban South
}

\author{
Africa \\ Mieke deGelder \\ University of Pretoria, South Africa
}

\begin{abstract}
In the HIV/AIDS literature, the tendency has been to avoid the agentive concept in favour of an emphasis on structure and subjectivity. Based on research with an HIV/AIDS project in Pretoria, South Africa, this article posits that examining how agency is locally conceptualized forms one route via which the notion may be plausibly inserted into the study of the pandemic. I evoke the figure of the 'ideal agent': the imagined AIDS sufferer against whose model actions those of actual AIDS sufferers are measured. Three stages emerge, the first characterized by victimhood, the second by moral transformation, and the third by the choice to 'go home to one's relatives'. In view of patients' impending deaths, local knowledge regarding proper burial and ancestorship, and the limited resources of the project, the ideal agent suggests how AIDS sufferers' agency is circumscribed and helps to clarify the volatility of the moral rebirth experience.
\end{abstract}

\section{KEY WORDS}

HIV/AIDS, agency, moral transformation, death, outreach, urban poverty, South Africa 


\section{Dear Virus}

I love you my virus, because

You are in me, I concentrate

On the way of

Dreams and life

You migrate

In my body, but the power

Of success is the key

To the way forward, to the

Vision. You will never

Control my body, my life

My mind, my future

Hey dear virus

I will never allow you

To control my entire

Life

I well remember the mid-September day I witnessed Ontibile, a young Tswana woman from a rural village some distance away from Francistown (Botswana), recite the above poem in the presence of a group of some fifteen AIDS sufferers, nurses and social 
workers. ${ }^{1}$ The occasion was a support group meeting of Ramatla Care Centre, an AIDS hospice located in the heart of Pretoria, South Africa, ${ }^{2}$ and I had come out to the event specifically to see how Ontibile was faring at this facility, to which she had been transferred a few weeks earlier. The poem, I admit, had me astounded: it was as if I was seeing and listening to an entirely different woman from the one I had first met at Thapelong AIDS Hospice in early July. In the presence of Toko - the Pedi social worker I had been accompanying to the latter hospice-and myself, that woman had wept inconsolably as she explained the essentials of her story, a subject enactment contrasting sharply with the upbeat image she was presenting now. And while Toko and I had already learned something of Ontibile's recovery some weeks earlier, this time it was not just the positive impression she made but especially the medium, the style she engaged in to substantiate this impression, that took me by surprise. Ontibile, I was intrigued to learn, had begun to write and perform poetry.

Ontibile's performance of 'Dear Virus' that spring morning bore witness to the moral transformation this young AIDS sufferer had been experiencing in the past few weeks, from the time she first entered Thapelong until the moment of the Ramatla support group meeting. In When Bodies Remember (2007) Didier Fassin describes this transformative process, arguing that it has taken on particular salience in South Africa in the time of AIDS:

Many narratives attest the same transformation in the way of life at the moment when the illness is discovered or in the time that follows. A painful change, sometimes preceded by a phase of denial but which at the same time heralds a new life, a sort of resurrection. Not only will nothing ever be the same again, but 
the inner revolution commands a strength that manages to stave off the announced death (Fassin, 2007: 248).

Fassin goes on to demonstrate how, despite the normative association of AIDS with death, the illness also comprises a 'vital dimension' which in South Africa is expressed through 'the discourse of the African Renaissance and in practices of moral regeneration' and also 'finally in that modest ambition: wanting to live' (Fassin, 2007: 249). Individual transformative experiences of AIDS have come to be embedded in a collective movement; in a 'moral revolution' which incorporates both religious and political modes of expression (Fassin, 2007: 257).

Shifting Fassin's theorization slightly, it could be suggested that Ontibile's recital and the narratives and diaries Fassin examines be read through the lens of the concept of agency. That Fassin does not explicitly do so is, in view of the existing literature on HIV/AIDS, not out of the ordinary; as I review below, the vast amount of social science scholarship on the pandemic has cautiously avoided the agentive concept in favour of an emphasis on structure. ${ }^{3}$ In the contemporary moment this tendency dovetails with anthropological approaches to agency more broadly, which have for some time been criticized for assuming the concept to be synonymous with free will or resistance (AbuLughod, 1990; Ahearn, 2001; Ortner, 1995) and more recently—and relatedly—for underestimating its humanistic underpinnings and ultimate rootedness in European intellectual, moral and theological history (Keane, 2007; Mahmood, 2005). Today, it appears, the volatility of the idea of agency often leads anthropologists and others to opt 
away from discussing it, while rather bare definitions such as 'the socioculturally mediated capacity to act' (Ahearn, 2001: 112) remain assumed.

In light of the observation that scholars of HIV/AIDS have largely shunned examining agency in view of the pandemic, this article offers a theoretical consideration of the concept through the lens of fieldwork conducted with terminally ill AIDS sufferers and their carers. In doing so, two pertinent points regarding agency bear mentioning at the outset. The first is that in the ebb and flow of everyday life agency is always circumscribed; it is always structured by the social conditions that inform its enactment (Ortner, 2005: 34; see also Wardlow, 2006). Second, conceptions of agency 'differ from society to society' and are variously 'related to notions of personhood and causality' (Ahearn, 2001: 113). Following these thoughts, I do not attempt a general definition of agency but instead focus on the question of how agency is locally conceived and constituted in the context of an urban South African HIV/AIDS outreach project. Within this fraught socio-medical domain, various 'types' of agency (e.g. 'agency of intention', 'agency of power') may be said to mesh together in practice — but these are further informed by such diverse factors as the popular rhetoric of 'living positively with HIV/AIDS', locally salient knowledge regarding death and dying, and the limited resources of the project. Taken together, a complexly constituted, roughly shared sense of what 'good action' and 'bad action' consist of emerges; yet even as both carers and AIDS patients are (potential) agents, their actions are clearly variously circumscribed.

How, then, is agency conceived within the project—a setting characterized by pervasive dying? In what follows I propose the abstract figure of the 'ideal agent': the imagined AIDS sufferer upon whose model actions the labour of outreach is 
predominantly premised, and against whom the actions of individual AIDS sufferers are persistently measured. Through this figure, three stages are incorporated into the everyday functioning of the project (cf. Erving Goffman's elaboration on the 'moral career of the mental patient' [1997 (1961): 63-71]). The first is that of the victim, characterizing the time a person with AIDS first enters the project. Often severely ill, such patients are considered victims of the pandemic and by extension of a host of 'social ills,' including poverty, family conflict and/or gender oppression; furthermore, they are imagined to have 'lost' their agentive capacities (to some extent), justifying caregivers' decisions to temporarily become agents for them; to engage in certain actions on their behalf. Over time — and given survival — this stage is to give way to a second: the moral transformation Fassin describes (2007: 248-260), when AIDS sufferers 'relearn' how to be agents in a fashion deemed 'good' or 'moral' by carers. Especially initially, the kind of agency promoted at this stage is powerfully premised on the ideology of 'living positively with HIV/AIDS' (see Roberts, 2005; Stein et al., 2003), ${ }^{4}$ and is deemed to include specific rights and responsibilities. Yet what this morally imbued action further consists of becomes expressly apparent during the third stage, which has the ideal agent travel home to his or her kin. Despite carers' cognizance that it takes some longer to pass through this trajectory than others, in the end the notion that patients had better 'go home to their relatives' denotes most powerfully the figure of the ideal agent, and concurrently speaks to the project's material constraints as well as carers' sense that AIDS deaths are 'bad deaths', the possible perils of which are best warded off by ensuring that the deceased are properly buried by their kin (Bloch and Parry, 1982; Dilger, 2008; Straight, 2006). 
Although few AIDS sufferers came close to resembling the ideal agent, the notion powerfully prescribed how caregivers perceived and indeed fostered certain forms of agentive action over others. The complexly specific ways these aspects became apparent through the outreach navigations of different patients and carers I explore below by concentrating on two AIDS sufferers, Abram and Ontibile. While Abram's situation will illuminate how caregivers take on —often ambivalently — the agentive capacities of the dying, Ontibile's will show how AIDS sufferers' agency is structured and circumscribed by caregivers' sense of the ideal agent - a reality that ultimately led to her exclusion from the project. ${ }^{5}$ In anticipation of the ethnographic analysis, I first briefly consider how agency has been conceptualized in the HIV/AIDS literature and in studies of death and dying.

\section{Agency and HIV/AIDS}

In light of the rapid rise in popularity of the agentive concept in the social sciences in the 1970s and 1980s (Bourdieu, 1977; Davidson, 1980 [1971]; Ortner, 1984; Taylor, 1985), it is notable that during this same time, the first full decade of HIV/AIDS, the notion remained markedly absent in investigations of the disease. During the 1980s much of the research focused on 'surveys of risk-related sexual behaviour' with the aim of collecting data that would benefit 'intervention programs designed to reduce behaviours associated with increased risk for HIV infection' (Parker, 2001: 164). Derivative of psychological theories of individual behaviour change, by the late 1980s these approaches came to be questioned by anthropologists and others on the basis of their limited cross-cultural applicative value. Along with the recognition that far more complex cultural, political and 
economic factors were at work in the structuration of risk in different population groups, it also became clear that the behavioural focus operated in the (re-)production of blame, attributing responsibility for the disease to individuals or collectivities (Farmer, 1992).

The dominance of psychologically and biomedically driven research agendas came to be challenged in the 1990s in two ways, in neither of which did the concept of agency come to play a major role. First, there emerged an emphasis on the interpretation of cultures as a key factor in coming to an understanding of the sexual transmission of HIV in different settings, and how such knowledge might contribute to the design of culturally appropriate prevention programs (Bolton and Singer, 1992; Setel, 1999; Treichler, 1999). While the focus of research thus shifted from 'strict' behavioural approaches to the cultural settings within which behaviour unfolds, it further became evident that parts of the relevant context were the economic, political and gendered factors that powerfully shaped sexual practices and experiences (Farmer et al., 1996; Singer, 1998). Implicitly or explicitly, subsequent HIV/AIDS studies have relied heavily on the notion of 'structural violence' and how different forms thereof determine individual and collective vulnerability (Biehl, 2007; Fassin, 2007; Lockhart, 2008; Wojcicki, 2002).

If in the concerted effort to understand and address the unequal distribution of the disease, scholars have strongly tended towards the structural side of the structure/agency dichotomy, the question of agency has persistently continued to hover beneath these approaches. In a careful manner, agentive matters are beginning to be addressed through studies of how agency is negotiated by persons whose lives have been violently shaped by such entwined forces as the capitalist economy and culturally specific gender expectations and differentiations - forces that lead them to engage in transactional sexual 
practices or multiple partnerships, placing them at a high risk for sexually transmitted diseases (Hunter, 2005; Wardlow, 2006; cf. Thornton, 2008). Others have initiated projects that subtly engage the agentive concept at arm's length, through considerations of how individuals and communities themselves make sense of the disease or attribute blame to certain agents (Ashforth, 2005; Dilger, 2008; McNeill, 2009; Niehaus, 2005; Robins, 2009; Thomas, 2007, 2008). Especially in this last, still emergent literature, the question of how AIDS deaths bear upon and transform the experience of everyday life is beginning to be addressed.

\section{Agency and 'bad death'}

One of anthropology's oldest topics, studies of dying, death and mortuary rituals have long been used to portray the effects of loss on persons, families and communities, to describe relations between persons and collectivities, and to expound on otherworldly beliefs. Following a person's passing, culturally and religiously sanctioned mourning and burial rites serve to establish closure and restore order to social worlds disturbed by death's interruption; at the same time death always implies vulnerability and possibly peril, and ritual processes need to be appreciated in their 'potential for failure' as well (Straight, 2006: 101; see also Bloch and Parry, 1982; Rosaldo, 1989).

It is especially with respect to the latter possibility that agency has come to take on salience in the investigation of death and dying. On the African continent, the concept's pertinence to these processes has chiefly been portrayed in relation to local notions and knowledge about the role of ancestors in the afterlife, including the ill will to which these otherworldly agents might be inclined should they be displeased through, for example, 
the neglect of ritual obligations (Bloch, 1971; Brain, 1973; Fortes, 1976; Goody, 1962;

Kopytoff, 1971; Rasmussen, 2000; Steadman et al., 1996). As Michael Jindra has shown for Cameroon, Christianity's indigenization may engender the proliferation of ancestors rather than their disappearance (Jindra, 2005; see also Weir, 2005). In addition, incidences of witchcraft, in the past often taken to refer to ideas about 'good, evil, causation, divination and healing' and contemporarily understood to be a 'complex historical phenomenon that... has evolved and changed markedly over time and is specifically tied to African forms of modernity', continue to thrive (Moore and Sanders, 2001: 3, 5-6; see also Ashforth, 2005; Comaroff and Comaroff, 1993; Geschiere, 1997; Rasmussen, 2004).

In many African contexts, advanced illness and bad or 'unnatural' death constitute events that lead people to agonize over their cause: is this one's ill fortune due to ancestral anger, the death of that one to witchcraft? In the time of AIDS these interpretive features of the African moral economy remain prominent and commonly converge with one or another version of the Christian narrative. Whatever a case's particularities, local conceptions of agency and their ascription to humans, ancestors, witches, spirits, demons or God —or to several at once—denote how agency is variously and complexly signified and negotiated in the everyday, entangled as it is with that which comes after. In this vein, construing a death as an act of witchcraft implies the 'imputation of agency to a perpetrator or perpetrators who might plausibly be considered motivated to harm the victim or those connected with the victim' (Ashforth, 2005: 71) —an explication that, in attributing blame to some, at once frees others from that burden. Or, should the violation of ritual prescriptions be identified as the locus of the problem-imbuing ancestors and 
descendants with agency — concurrently a door opens that may lead to appeasement and the restoration of moral integrity (Dilger, 2008: 210). In yet another elucidation death may be due to divine punishment or Godly indignation — but who is to say what mediums he might have engaged in the distribution of his ire?

In sum, the unavoidability of death HIV/AIDS entails raises vital questions regarding the pandemic's interpretation and how such understandings are shaped by knowledge about who — or what—can be an agent and what sorts of actions they might, should, or actually engage in. Yet in the HIV/AIDS project, such issues were rarely openly discussed. The labour of outreach was ambivalently situated at the vulnerable margins between life and bad death; a composition that emerged highly paradoxical and potentially perilous, in part because the kin of most patients - those who, in the dominant perception, should ideally become agents on behalf of ill or incapacitated relatives; who should bury them — were absent. Carers thus occupied a markedly contradictory position: though 'strangers' to those in their care, they daily engaged in such intimate, mundane tasks as preparing meals, cleaning beds, ensuring that medications were taken, bathing and clothing patients, changing diapers, taking them to the hospital—all activities normally considered part of the domestic or familial sphere. In essence, they become 'family members' of AIDS sufferers - but as per the figure of the ideal agent, in light of the knowledge that AIDS ultimately leads to death, this role is meant to be and arguably cannot but be temporary. It is at the 'moment' of patients' deaths - a time hard to pinpoint since death is always hovering (cf. Niehaus's portrayal of AIDS suffering as 'death before dying' [2007]) — that such kinship fails, for it is of utmost importance that the deceased are buried by their relatives - the only agents able to ensure that the transfer 
from earthly existence to that of the hereafter proceeds in the appropriate cultural or religious manner. Rather implicit in the context of the urgent practical labour carers were constantly conducting, such tensions give some indication as to why occurrences of bad death and what comes after were largely 'impossible' to speak about. ${ }^{6}$

\section{'What to do with Abram': a case of agentive uncertainty}

In essence the main function of the project was to manage a particular category of persons and bodies: those infected with the HI Virus or (more commonly) those whose bodies were being or had been ravaged by full-blown AIDS. Yet precisely where does the distinction between these entities lie? Although nurses, doctors and social workers never quite articulated the matter thus, this question seemed to hover beneath many of the discussions I observed and participated in regarding people who had AIDS. It was understood that persons and bodies ought to be handled differently, and more tacitly that the living and the deceased possessed different kinds of agency, but how best to assist the extremely ill—-the dying and the 'almost-dead'? What of their desires, should they still be able to express them? What of their rights, even if they were considered to have lost the capacity to communicate? And beyond the 'moment' of death, what constituted a respectful, appropriate burial?

In the various regions that collectively bore on the project, such ambiguities were constantly alluded to in discussions and conversations. Consider, for instance, the case of Abram. According to the nurses Abram, who was wheelchair-bound, had been brought to Lesedi Clinic (in addition to Ramatla and Thapelong, the third institution the project ran) by 'this guy', apparently a neighbour who had refused to give his name. That same day 
he was transferred to Thapelong, where Toko and I encountered him a few days later. Unlike the other patients quietly watching Dr. Phil on the old television in the hospice's living room, the nurses had put Abram in his bedroom 'because when he is with the others he screams and cries the whole time.' We found him sitting crookedly in his wheelchair, silently staring out of the window. As the nurses had alluded to, our appearance indeed produced tears, though in truth Abram's crying was more akin to a steady, deeply distraught wailing. At moments such as these Toko's responsibility was not merely to console but also to collect as many details as she could about a patient-a task she usually launched into following just a few short moments of 'necessary comforting'. In Abram's case, however, she encountered a substantial stumbling block. Amidst his devastating cries he was formulating words and sentences, but Toko was largely unfamiliar with Xhosa, the language he was speaking.

Back to the nurses and patients gathered around Dr. Phil in the living room. 'Does anyone know Xhosa? Can you help us understand what Abram is saying? Please?'

Ntombi, looking barely older than 20 , reluctantly put her small baby on the rug in front of the television and shuffled alongside us to Abram's room, steadying herself on the passage walls. Abram had fallen quiet, but our return immediately induced further weeping, interspersed with what seemed like a myriad of Xhosa expressions. Seating herself on the edge of one of the beds, our translator first listened to Abram, then tried to converse with him.

'He says... He says many things, what he says does not make sense.'

'What is he saying, what are the words he is saying?' 
'He says he want to go home now. He says his legs and feet hurt. He says he want to see his dad.'

'Can you ask him, where is his home?'

'He only says he want to go home... He says he had the stroke.'

'Please, can you try to ask him again? Where is his home, where is his family, what is the telephone number?'

'Aowa [Pedi, no], what he says... He says Eastern Cape and he says Cape Town, he says he want to go home... He says again, his feet hurt. ... Now he is talking about the jail. He says he want shoes, he does not have the shoes. He says he is afraid of God, God is angry because of what he did, he want to see his dad. ... What he says does not make sense!'

Ntombi was getting frustrated with the ostensibly confusing mix of memories and desires ('non-sense') Abram was articulating, so Toko said it was fine, she could leave. She would ask Sister Maria, who would be on duty that evening, to try to get more information from him: 'I think maybe she's Xhosa.'

The details Toko and others collect from those visiting the clinic or staying in a hospice — frequently a difficult and wearisome task — become part of the project's activity and artefacts. Initially scribbled hastily in a notebook, they are taken to one office or another where they are formally written up in a report and filed. Then follow meetings during which such official documents reappear, and where they are briefly or extensively discussed depending on the urgency of a client's situation. Likewise, Toko brought up Abram's case during a meeting with her co-workers: 
Toko: [We need to talk about] Abram, the one in the wheelchair. He is at Thapelong and he wants to go home and see his dad in the Eastern Cape. I got a hold of his aunt in Cape Town. ${ }^{7}$ She told me that his parents are dead and that he has a brother who is in prison in Kimberley. So I talked to Sister Matla and Dr. Ntsako. Sister Matla said we need to send him home first, and there his own family can tell him that his parents are not alive anymore. Send him to Mangwaneni in the Transkei. Take him there and there they will tell him. But first he needs to get on medication. He has no papersAndrea: [interrupting] Where are we sending him?

Miranda: It should be up to him to decide, where he wants to go!

Andrea: Toko, tell us, what is right in your culture?

Toko: ...I'll speak to Dr. Ntsako.

Andrea: No, but, what should we do, what is the right thing to do?

Toko: ...It's not right, it's rural! There's no one! Everyone from the Eastern Cape is coming here!

Miranda: And they will just leave him there! Does he have extended family? Where is his family if his parents are dead?

Toko: There is one in Cape Town. That's the one I talked to, she told me about his parents and brother.

Miranda: What's the reason why he wants to go home?

Toko: It will be more expensive if he dies here.

Andrea: He says he wants to go home, he wants to die at home.

Toko: Dr. Ntsako says that area is so rural, it's in the mountains, it's bad! 
Andrea: He is in need of a caring facility, a place where he can be taken good care of, but he wants to go home...

Toko: What should I do? I don't know! Should I tell him [about his parents]?

Miranda: He has the right to know. Right now what is happening is not ethical.

Toko: But he is very sick, I think he doesn't understand things, he's very confused. And he is always crying. At Thapelong the other patients say he is crazy.

In this excerpt the question of 'what to do with Abram' is discussed by three women: Toko, his social worker, Miranda, an Afrikaner social worker, and Andrea, the others' Afrikaner manager. Toko introduces the case by reporting on the current state of affairs, including the activities she has thus far engaged in. She is about to explain a process those working with AIDS sufferers are all too familiar with—Abram needs to get on antiretrovirals (ARVs) before he can go home, but before this can happen he needs to get his papers in order so he can apply for an AIDS grant - when she is interrupted by Andrea. 'Where are we sending him?'

The ethical doubts and ambiguities expressed here are multiple, appearing jumbled together in a puzzling manner. Initially and characteristically, as I had learned by then, Toko's way of addressing the matter was to keep back her own thoughts and continue with those activities she daily tackled: apply for an ID and an AIDS grant for Abram; get him on a treatment regimen. These pursuits would take at least some weeks, and who knew what Abram's condition would be a month from now? Andrea's question, however, leads her to reveal strong doubts about (eventually) sending her client to the rural region of the former Transkei he appears to be from. She is in agreement with Dr. Ntsako: the 
rural areas are 'bad', 'there's no one!' ${ }^{8}$ Yet she is also aware that it will be costly to keep him in the city for both hospice and government, specifically should he require a pauper's funeral. Moreover, such interments, which for Toko and many others signify the epitome of a disrespectful, improper burial, are considered the very last resort, to be proceeded with only if relatives cannot be traced or if they fail to show up to take a family member's body home (cf. Bähre, 2007: 40, 42; Scheper-Hughes, 1992: 249-267).

But what of Abram's rights - the right to go where he wants to go, the right to know his parents are dead - an issue most fervently expressed by Miranda, though also alluded to by Andrea through her emphasis on Abram's articulated desire to go home?

The embodied condition that constitutes Abram's and other AIDS patients' suffering emerges as one that is neither 'fully alive' nor 'fully dead'; rather, it uncertainly hovers between these two culturally and religiously perceived domains. Of course Toko, Andrea and Miranda know that Abram is alive, not yet deceased, and that as such he possesses or should ideally possess the capacity for action with which humans are thought to be imbued; yet they are equally well aware that his person-status, his ability to act and make his own decisions, has been severely compromised and may soon be coming to an end. Toko's recognition of her client's looming death is what leads her to become an agent for him; to carry out certain activities on his behalf which, she hopes, will result in the recovery of his health and agentive abilities: the first stage recognized in and through the figure of the ideal agent.

In one sense the concerns expressed by Miranda and Andrea regarding the issue of Abram's rights appear to challenge Toko's approach. Their questions are rooted in the discourse of rights; a discourse that, in broad terms, can be read as problematizing any 
situation wherein one person or collectivity assumes the role of agent for another. Thus they query Toko: 'Where are we sending him?' 'It should be up to him to decide, where he wants to go!' 'He has the right to know.' Yet even as these outreach workers berate their colleague for what they perceive to be her presumption that Abram's agentive capacity has so far deteriorated that she cannot but become his agent, it is important to recognize that their aims do not, in the end, differ greatly from hers. Their final objective is the same: to ensure that Abram's rights- and responsibility-bearing person-status is sustained; that he remains his own agent. That their approach to this common end differs is attributable to the fact that Toko has met and worked with Abram, whereas Andrea and Miranda have not.

However uncertainly constituted in the fraught socio-medical arena of the project, what becomes apparent is the dominant salience of a type of knowledge that, emergent from the long history of Christian-humanist thought and closely tied to the idea of modernity as moral progress or liberation, envisions the human subject as a free, self-aware agent (Keane, 2007: 55; see also Harri Englund's critical assessment of the discourse of human rights as 'freedoms' in Malawi [2006]). As the above debate also shows, specific circumstances — such as advanced illness—reveal how this notion is further tied to a certain idealization of kinship relations, for the parallels commonly drawn between agency and human freedom concurrently assume the health of the human subject. When this health is compromised or a death occurs, 'the family' emerges as the prime locus that ought to take on the role of decision-making for an incapacitated or deceased person. This in some senses paradoxical idea of the entwinement of human freedom with familial dependency and responsibility emerges clearly in the above discussion: 'I got a hold of 
his aunt in Cape Town.' 'Does he have extended family? Where is his family if his parents are dead?'

In Abram's case caregivers' attempts to locate relatives — other than the aunt in Cape Town - proved futile. His condition began to deteriorate rapidly about two weeks after the meeting just discussed took place; the next month he passed away, still at Thapelong. Following his death his aunt told carers that she was unable to come to Pretoria to collect him for burial. Accordingly, Abram received a pauper's funeral. The nurses at the hospice had estimated him to be in his early to mid-30s.

As noted, the question of what happens to people after they die was rarely mentioned, let alone discussed. In ways sensible yet profoundly ironic, the objectives of the project were squarely situated in the realm of human life; it sought to address the needs of the living, not those of the dead. And although the latter issue did relentlessly interrupt the task at hand, it was as if it was constantly, and perhaps equally relentlessly, being pushed away. Nonetheless, what was not expressed orally tended to become apparent allusively, at times through the modes of anger or fear, and often only over the course of time, through the outreach navigations of AIDS sufferers who were still considered to have a chance at life. In such cases the tension between 'respectful care' and the urgency with which patients were motivated to 'go home' would grow ever more intense as the months passed - revealing, as Ontibile's account will show, the simultaneity of the project's reliance on the imagined figure of the ideal agent and the limits this conceptualization finally imposes. 


\section{The 'failure' of a poetic agency: Ontibile}

'Basically dying': Thapelong

The start of Ontibile's traversing the outreach network coincided with my own arrival in Pretoria in the winter of 2006, when I first began to accompany Toko on her weekly trips to Thapelong. At one time a Dutch Reformed parsonage, the building had been purchased by the HIV/AIDS project in 2003, whereupon it had been converted into a 20 -bed facility for 'homeless people who are terminally ill'. In the words of one caregiver, Thapelong's objective was to provide a space where 'the poor can die with dignity', though in my mind the place came to resemble something more akin to Vita, that 'zone of social abandonment' in the Brazilian city of Porto Alegre so hauntingly brought to life by João Biehl and his interlocutor Catarina (Biehl, 2005). The persons who passed through Thapelong's doors, who wandered its halls and were confined to its beds, inhabited bodies that could no longer conceal the utter misery of the AIDS pandemic. Whatever illnesses the virus manifested itself in from one body to the next, death was always lingering nearby, always hovering somewhere around a corner. To make matters worse, and in ways disturbingly reflective of patients' conditions, the place was generally unkempt, and conflicts between and among nurses and patients were common occurrences.

Ontibile entered this fraught domain in early July, where Toko and I met her on a Tuesday. I remember being struck by how quickly Ontibile's face changed from one of laughter and giggling to one flooded with tears - a transformation that remains especially vivid, I fear, because it was I who naively asked her the question that produced it. 
Ontibile had been informing us of her situation — that she was 26 , had left her village in rural Botswana in 2002 to study in Gauteng, had been living and working in Atteridgeville township, and that her CD4 Count was 130 - and Toko had accordingly initiated the process of assisting her.

'If you have a CD4 Count that is higher than 200, then you are not allowed to get a disability [AIDS] grant. But if it is below 200 you are eligible, neh? It means your immune system is weak so you can't work, so there is this financial support. If it is higher than 200 you can work. ${ }^{9}$ Are your papers valid?'

'I have this... [showing us her Botswana ID] In August, for three years I don't have the papers.'

'Okay. The way you qualify for the grant is, you first have to get an affidavit at the police station and then apply to Home Affairs to renew your permit. I can write the letters to help you with that. I am here to help you. Okay?'

A momentary silence ensued as Toko and I hastily scribbled things down in our notebooks. Toko, who had come to assume a kind of teacher role in regards to me, had been encouraging me to ask questions, and I decided to seize the moment and pose a question that had been running through my mind. 'Would you like to go back to Botswana?'

Ontibile's expression instantly changed, and I noticed several large tears beginning to trickle down her thin face. I was vastly thankful for Toko's presence, who quietly put her arm around Ontibile and let her cry for several long minutes. She eventually spoke, but my query had clearly devastated her: she continued to weep throughout the remainder of our meeting. Ontibile proceeded to explain that she feels she cannot go home, since she 
has not told her kin about her illness. 'That side' she is from in Botswana 'has no electricity', she clarified; it is small, rural and poor, and many of the people 'don't know about this AIDS'. 'She is afraid of stigmatization', Toko later said; 'I think she has not yet accepted it that she is positive.'

In the following weeks Toko and I saw Ontibile regularly at Thapelong's support group meetings. As promised, Toko wrote letters supporting Ontibile's application for an affidavit and renewal of her temporary visitor's permit. In essence these steps were identical to the ones she followed in her counselling work with Abram: when it came to those of her clients who had AIDS, she considered it her primary task to ensure that they would be put on a treatment regimen. State hospitals required a three-month period during which patients were checked monthly to gauge their reaction to one combination of medications or another; hence, in Toko's estimation, Ontibile would need to stay in Pretoria for several more months, since she was not yet on ARVs when our paths had first crossed in July. Concurrently the ambiguities surrounding clients' rights also surfaced dubiously in Ontibile's case. After meeting her for the first time, for instance, Toko (backed by Andrea) insisted that Ontibile 'does not have to tell her parents' about her status; 'it should be her choice, it's not our choice to make.' Yet two days later, following Thapelong's support group meeting, I observed her suggesting to Ontibile that she look for a social worker who would be able to accompany her to Botswana.

Amidst this perplexingly mixed set of messages, Ontibile's stay at Thapelong soon proved laden with conflict as well. Her problems with Sister Matla, she asserted, arose because her medical file was at Kalafong (the state hospital on Atteridgeville's periphery where she first tested positive): she was supposed to begin treatment on the $29^{\text {th }}$ of June, 
but now it was mid-July and 'I still don't have the pills!' Thapelong's patients tended to seek treatment at Pretoria Academic — a state hospital nearer to the hospice—and it was to this massive medical establishment that Ontibile's file needed to be transferred. 'But no one will take me to Kalafong!' Ontibile's frustration here made sense, though I was less certain of Sister Matla's allegedly negative role in the whole affair. How could Ontibile hold Thapelong's head nurse responsible, whose duty it was, after all, to remain on the hospice's premises and look after the patients?

\section{'Strong enough': Ramatla}

Ontibile's early August move to Ramatla initially proved positive. Amongst friends and acquaintances in outreach, this 10-bed hospice aimed at 'people who are chronic with HIV and related illnesses' tended to be distinguished from Thapelong on the basis of its somewhat different objectives. Ramatla, they said, was a temporary housing facility whose patients would eventually be 'strong enough to return to society'; their medical conditions differed from those of Thapelong's occupants, who were 'basically dying'. Although I witnessed many a transfer between the two sites, that there was some truth to this distinction seemed conspicuously reflected in the material and social conditions differentiating the two places. In contrast to Thapelong, Ramatla was clean and well-kept, and even its support group meetings appeared more organized and goal-oriented than did those at its sister hospice.

Importantly, it was at Ramatla that Ontibile first began to write poetry, and it was also here that she became an eager support group participant, primarily through the encouragement of Felicia, a white English-speaking South African social worker. At the 
outset Ontibile's needs and desires seemed to align well with Ramatla's objectives regarding the notions of rights (the right to treatment and self-expression as a positive person) and responsibilities (the responsibility to get tested and 'embrace' one's positive status). In line with the ideology of 'living positively', where seropositivity comes to be seen as 'something good' (Roberts, 2005: 76), at Ramatla these were considered pressing concerns, and Ontibile's efforts to address them with the help of Felicia and others ensured her budding status as a kind of model outreach client. She began to take ARVsa combination of four medications - on the first of September, and the poem 'Dear Virus' powerfully captures her sense of a transforming self, a self progressively moving from being controlled by the illness towards accepting, owning, and even (purportedly) loving it: the ideal agent's second stage.

In a further development, Ramatla's staff also encouraged Ontibile to contact her relatives. Accordingly, following one support group meeting, she excitedly informed me that she had spoken on the phone with her mother and older sister. She had not seen or heard from her family for three years, ever since she had chosen not to return home after finishing her classes. She shared that her five-year-old daughter, who was living with her parents, was doing well and had grown very tall (Ontibile giggled: 'She thinks I'm her sister, that's what she calls me, sister!'). Most significantly, she asserted that she was making plans to return home in December: 'After three months I can transfer my file to Francistown.' Yet when I carefully sought to ascertain whether Ontibile had discussed her illness with her mother, her immediate reaction was an embarrassed, wordless grin. Some minutes later she whisperingly acknowledged that she had told her sister, "but my parents, they think it's just TB.' 
One morning in mid-October Toko and I were having coffee at one of the network's NGOs, near Lesedi Clinic, when the organization's secretary rang: 'Toko, there's a client here to see you.' Toko pulled a face, mumbling that she had no appointments and would be back soon, only to animatedly re-enter the office a few moments later: 'Come see who the client is!' Seated beside the secretary Ontibile laughed in response to our elation, covered her face with her hands - and promptly began to cry. Conjuring up a familiar scene, her tears shocked us nonetheless.

What had transpired? Her account emerged complicatedly, tacking back and forth from one patient at Ramatla to the next, from one caregiver to another. In a convoluted mix of Tswana and English something approaching the following narrative emerged:

Today at Ramatla they told me to pack up and leave! I don't get along with everyone there and they told me I have to go! But I have nowhere to go! And today I'm supposed to go to Kalafong because I don't have the pills anymore, they gave me money for the taxi but then Sister Ntsiki took the money back! I don't know what to do; I don't know where to go so I walked here to find you... [...] I fought with Promise because she wanted to watch eTV but I said I wanted to watch Muvhango on SABC2. And Solomon, he is always picking the fights! They call me a foreigner, they say I am not welcome because I'm a foreigner and I have to go back to my own country! ${ }^{10}$

Toko and I decided to take Ontibile to Kalafong, though Toko first phoned with Felicia (who, unaware that Ontibile was being expelled, promised to 'look into it', adding that 'she can be naughty sometimes') and furthermore insisted on dropping by the hospice. To 
say the least, the scene that unfolded there rendered us all but speechless. Upon arrival we were told to sit at the table in the communal kitchen, where each person present- - nurses, patients, cooks, cleaners—gathered in a circle around us. Sister Ntsiki joined the group in such a state of anger that Toko's efforts to discuss anything proved largely futile; clearly the mere sight of Ontibile provoked intense resentment in her:

You want to know why I'm kicking her out; I'm kicking her out for two reasons! First, she's naughty and she has a big attitude problem! Ramatla is a free service, she don't own this place, I don't own this place, nobody owns this place! Ontibile acts rude but she's getting everything for free here! She should be thankful instead of creating trouble but that's all she does, create trouble! The second reason is, there's a six week limit on staying here and she's been here for more than two months already. I want her out today! [...] Yesterday I asked Sibusiso to take her to the shelters so she can find a place to stay. He took her to two but no, she don't want to stay in them! She don't want to live there! Nothing is good enough for her! But I'm telling you, we're finished with her here, she's healthy now, she's gotta go!

Eventually Sister Ntsiki relented slightly: Ontibile would be allowed to sleep at Ramatla two more nights, giving Toko some time - albeit very little — to arrange alternative accommodation for her. We spent the remainder of the day waiting in long queues at Kalafong's Immunology Clinic, and two days later Ontibile had little option but to relocate to Visagie Shelter. 
'My ARVs are my boyfriends': Visagie Shelter

Although these events signified Ontibile's departure from the immediate institutional nodes of the project, she did not disappear from outreach circles altogether. Managed by the Gauteng Department of Housing, the overcrowded shelter she came to live in was one of Pretoria's largest. It housed some 300 men and 100 women and children, several of whom relied on the outreach network for food parcels, medications, and the occasional low wage job. At six o'clock each morning the shelter's residents—aside from the elderly, the sick, those unable to walk and women with small children or babies-were forced to leave the grounds until six in the evening, when its high gates once again swung open to allow people in for the night. Other than sporadic donations of bread, pap [Afrikaans, stamped corn] or rice occupants were expected to look after their own needs, including food, clothing and blankets. Through Toko's efforts, Ontibile began to receive food parcels on a biweekly basis.

Ontibile's departure from Ramatla coincided with what for me constituted an important development in our relationship, for it was during this conflicted time that she began to share some of her writing with me. Noticing my interest in her poetry, on the Tuesday Toko and I took her to Kalafong she gave me two poems (typed and printed on one of Ramatla's computers) and further permitted me to copy 'Dear Virus' from her notebook. From that moment, she would occasionally show me her work or text-message a poem to my cell phone.

It was Ontibile herself who proposed a way in which I might go about reciprocating this gift, for on the morning following her first night at the shelter my flatmate woke me at 6:30: 'Mieke, you have a visitor!' Rubbing the sleep out of my eyes, I found Ontibile 
already seated on the couch in our tiny living room. The women I lived with quietly went about their morning tasks whilst I, for the second time that week, witnessed Ontibile's laughter turn to heavy tears as she searched her baby blue handbag for her treatment regimen.

'Did you have anything to eat this morning?'

'No... I have to eat before I take the pills but I don't have food, I don't have money...' I prepared toast and instant coffee and sliced some oranges for us to eat. In the meantime the news of Ontibile's unexpected visit appeared to have done the rounds, for Toko soon showed up on our doorstep. Toko sat with us for a while, allowing Ontibile to finish off a second orange, but then urged us to come downstairs to Lesedi. Handing Ontibile a food parcel, to my consternation she proceeded to tell her in no uncertain terms that she was not permitted to visit me at the flat again: 'Ontibile, Mieke lives in a private flat, you can't go there in the morning anymore, you shouldn't go there at all. It's a private flat, you understand?' My hesitant attempts to intervene fell on deaf ears as Toko continued, 'You need to go back to Botswana, neh? You'll stay until December because they have to monitor you at the hospital, but then you need to go home because your support system is there. Okay?'

In the months that followed I saw Ontibile fairly regularly, though there were weeks when we did not meet, whether due to my own schedule or her 'temporary disappearance' from outreach circles. At times she visited me at the flat or I took her to Kalafong for her monthly check-up—or, alarmingly, we would hear from one acquaintance or another about her having collapsed 'again' at the shelter or on the street (Ontibile was taken to hospital by ambulance four times between November 2006 and 
May 2007). Whenever Toko and I visited her following such incidents, Toko would urge her to go home. 'What if the day comes when we're not here to take care of you?' Through the grapevine we also heard other stories. 'Eish, Ontibile, that one, she's hanging around with bad people at the shelter!' 'She's having many boyfriends!' Although it was exceedingly difficult to disentangle fact from fiction regarding such rumours, Ontibile's phone call to tell me that her friend had given her a cell phone for Valentine's Day led me to cautiously bring up the issue when she next visited me. 'Aowa Mieke!' she giggled, 'it's not true, he's just a friend! My pills, my ARVs are my boyfriends.' Some weeks later she confided that another man at the shelter had asked her to marry him, but that she had declined his offer. 'I told him, why should I marry you, I don't know you!'

I never officially interviewed Ontibile in the sense that I used a recorder, a device of which many of my friends and acquaintances in the inner city were more than a little sceptical. She rarely volunteered details of her life in Botswana other than those concerning her rural origins, the fact that she had a daughter, and that she belonged to the Zion Christian Church, and appeared equally reluctant to talk about the four years that had passed since crossing the border. The little I knew was that she had come to South Africa to study at an 'upholstery school', that her link to the country had been the father of a friend in Botswana who was a South African, and that she had been living with friends in Atteridgeville before being diagnosed, first with TB and then with AIDS. Once, when I asked her about her friends in the township, she enigmatically replied 'They think I am a ghost.' It was the only comment she ever made about them. 
What I was left with—or what she left me with—were written words: poems that spoke compellingly of 'being HIV' and 'having a vision' in spite of it, of Ramatla as 'the mother I have now', of dreams of being a 'married woman'. Above all, Ontibile's poetic renditions bear witness to what, trapped in extreme conditions of poverty and illness and living amongst 'flying gossips' and 'ever right people', she was so frequently prevented from expressing in ordinary conversation. Consider, for instance, the poem 'My Confidence', which she wrote shortly after her expulsion from Ramatla:

I'm feeling vulnerable

I'm different to myself

My passion has declined

I'm filled with anger

Happiness please fight my anger

Confidence may you boost my self-esteem

My confidence is my hero

While my worries are my enemies

Come and live in my blood veins

I mean you my confidence

The flying gossip won't help

The ever right people won't do much better

But the level of my trust 
And the ego to go on

Shall be my strength

My confidence is my success

Clearly Ontibile's words here still evoke her Ramatla days, the language she learned to write and perform during her time at this hospice: 'Come and live in my blood veins, I mean you my confidence.' One of the last poems I received from her, 'It's Autumn', reveals a distancing from this kind of morally imbued writing, and simultaneously constitutes a poignant expression of the fears and desires that lay at the heart of her performance of the self:

The parents finished their task

They brought these seeds up

All of them were well taken care of

We the daughters must wake up

If not, autumn will frustrate us

Me daughter of Mthimkulu

I'm still single in autumn

What am I waiting for

The princes are well groomed

My heart is a stubborn rock

This autumn is my last chance 
I have everything except courage

I have everything but lack charity

Oh my forefathers help

When will I overcome this wall

But finally I'll be in love

I need love

At the time of writing Ontibile continued to stay in Pretoria, though no longer at Visagie Shelter. In June 2008 a violent incident occurred near the shelter's premises, during which she was stabbed by a male resident who accused her of sleeping with him without having disclosed her seropositive status. Following this event Ontibile relocated to a women's shelter in the inner city.

\section{AIDS death and the limits of agency}

Through an analysis of how agency is conceived within an HIV/AIDS outreach project in Pretoria's inner city, this article has proposed one way in which this often assumed concept may be inserted into the study of the pandemic. I have argued that the abstract figure of the ideal agent indicates how, in South Africa's HIV/AIDS context, caregivers conceive of agency and indeed struggle with questions over who possesses agency, when, and of what kind. The three stages broadly recognized in and through this figure illuminate how agency is a far from stable notion, even within the confines of the project. Thus, upon terminally ill persons' entrance into the project, the idea of victimhood 
motivates carers to become agents on patients' behalf. Yet even as their actions are meant to ensure patients' arrival at the moral rebirth stage, the sense of impending death may simultaneously engender a harried process of trying to locate clients' relatives. At the first stage the overt notion of victimhood, then, is subtly entangled with locally salient knowledge regarding death and dying, particularly the sense that AIDS deaths are bad deaths. Granted a person's passing, denoting the 'end' of his or her human agency, ensuring a proper burial by kin is deemed best both for the deceased and the relatives involved.

Notably different, the second stage is informed by a sense of agency premised on the ideology of 'living positively with HIV/AIDS' so popular in present-day South Africa (Roberts, 2005; Stein et al., 2003). In the outreach project this stage, signifying the moral regeneration of the AIDS sufferer, is understood to incorporate specific rights and responsibilities; hence alongside the responsibility to get tested and to confidently respond to one's diagnosis, patients here are further taught to embrace and insist upon their rights to treatment and self-expression. Of the different forms of agency persons (or bodies) who have AIDS are thought to possess or encouraged to enact at different stages, the kind imagined to warrant moral regeneration is most clearly derivative of the humanist ideology of self-transformation (see Keane, 2007: 3-4). Lastly, it is particularly at the third stage that the responsibility facet of the moral rebirth coin comes to include the appeal for AIDS sufferers to return home to their families. While this appeal is partially prompted by the project's constrained resources, including the limited number of beds and carers, it also remains produced by the knowledge that for persons with AIDS, death—though perhaps evadable for a time —is ultimately inescapable. 
If the ideal agent goes some way to explain caregivers' management of HIV/AIDS in the inner city, it is further apparent that AIDS sufferers almost never exercise the model sort of agency this figure signifies. As Abram's situation exemplifies, sometimes they are simply no longer able to do so; indeed Abram was but one among many who never made it past the stage of being a victim. Even when a kin member was finally traced she failed to come, and he was left to die at Thapelong and be buried by the state- the quintessential bad death. In the situations of patients like Ontibile, those still thought to have a chance at life, the ideal agent figures more prominently: there is a path that opens up; there are rights to be insisted upon, responsibilities to be embraced. Ontibile followed this trajectory remarkably well until it became clear that she was not about to return to Botswana. It was then that she came to be considered a 'bad patient', one who had outstayed her welcome; not even her poetry—initially celebrated as a fine example of what the ideal agent might do-could salvage the situation.

One concluding point to be made about how terminally ill AIDS sufferers' agency is conceived within the project, then, is that it is often imagined to be present either in deficit, as with Abram, or in excess, as with Ontibile. While this observation compels agency's examination in view of the pandemic, it simultaneously leads us away from any kind of celebratory, unproblematized reading of it. If tacitly, Fassin also recognizes this when he notes that ' $[w]$ here AIDS is concerned... it would be a mistake to exaggerate the practical effects of [patients'] moral transformations' (2007: 259). Yet what agency's theorization further allows us to ponder is the how and why of the precariousness of AIDS sufferers' moral rebirth experiences. Clearly in the outreach project, agency is predominantly understood to be roughly equivalent to the qualities of resistance and self- 
determination. At the same time its reliance on these notions, via the creed of 'living positively', is constantly compromised by the knowledge of impending death for most patients — and beyond that, by local conceptions regarding burial and ancestorship — and the project's limited resources. Powerfully circumscriptive of AIDS sufferers' agency, these factors help to make sense of the oft-ambiguous character of patients' experiences of moral transformation.

\footnotetext{
${ }^{1}$ Aside from major cities, townships, neighbourhoods and hospitals, all names evoked in this article are pseudonyms. The three poems evoked in this article Ontibile wrote in English, though she also produced Tswana poetry.

${ }^{2}$ The research on which this article is based was conducted with an extensive faith-based outreach network in Pretoria's inner city in 2006/07. The establishment and rapid growth of this locally-initiated endeavour, which today has several churches and NGOs partnering together, coincided with apartheid's demise in the early 1990s and the momentous demographic shift the inner city subsequently witnessed.
}

${ }^{3}$ As attested to by, for example, the biographic approaches employed by Fassin et al. (2008) and Niehaus (2006), scholars have not ignored the agency of people afflicted with HIV/AIDS. The point, rather, is that the notion has not been developed theoretically within this body of literature.

${ }^{4}$ Roberts describes a 'positive identity' as a 'resistance identity' (2005: 24, 78; drawing on Castells, 1997), revealing how the ideology of 'living positively' is closely tied to an implicit conceptualization of agency as resistance. In South Africa this signification is also strongly linked to the visibility and popularity of the Treatment Action Campaign (TAC) — the most effective social movement to have lobbied for the rights of persons living with HIV/AIDS (see Robins, 2008).

${ }^{5}$ The point of Ontibile's eventual exclusion is significant, and validates an examination of her outreach navigations via the agentive concept. From a different vantage point, her recital of 'Dear Virus' (and the moral rebirth she underwent while at Ramatla more generally) can be considered as performative in the sense that it was seen as constituting her acceptance of the illness. Yet what is further at stake within such performed and performative moments is the manner in which they are interpreted, by individual AIDS 
sufferers and those around them and at specific times, as 'good' or 'moral' forms of action —as different from, that is, 'bad' or 'immoral' action (or even 'no action at all') at other times. In view of the dire situations of many persons with AIDS, it is important to ask how value is differentially attributed to their actions, and how such ascriptions function in the everyday negotiation of their circumstances.

${ }^{6}$ The silence surrounding death in the outreach project should also be read, following Fraser McNeill, not as an instance of 'collective denial' about HIV/AIDS but as 'an attempt to create "degrees of separation" between an individual and a cause of death', a practice the significance of which reaches beyond the pandemic to embrace any death perceived to be unnatural (2009: 356).

${ }^{7}$ It was indeed with the aid of Sister Maria, a Xhosa speaker, that Toko had managed to obtain this information.

${ }^{8}$ Amongst my black interlocutors Toko was not alone in holding this at times vehemently expressed view, supporting Achille Mbembe's thesis that 'most social struggles of the postapartheid era can be read as attempts to reconquer the right to be urban.' Apartheid's end, he suggests, raises anew the question of how to be 'at home' in the city—a question particularly urgent for blacks since the city 'has been the dominant site of their exclusion from modernity' (2004: 391, 393).

${ }^{9}$ The African National Congress (ANC)'s termination of Thabo Mbeki's presidency in September 2008 signalled the end of the deeply embattled approach to HIV/AIDS taken by the ex-President (see Fassin, 2007; Posel, 2005). If the Mbeki government refused to distribute ARVs until November 2003 (and then only to AIDS sufferers whose CD4 Counts fell below 200), newly elected President Jacob Zuma appeared to live up to his promise to change government's tactic when, in December 2009, he announced that ARVs would be made available to all HIV-positive South Africans (and other legal residents) with a count of 350 or less. Normal adult CD4 Counts range from 500 to 1200; with seropositivity the count gradually decreases, increasing the risk of opportunistic infections and thus, of death.

${ }^{10}$ Ontibile's claim about being called a foreigner was likely not unfounded. On the 'xenophobic violence' that has gripped South Africa in recent years, particularly in May 2008, see Sharp (2008). 


\section{References}

Abu-Lughod, Lila (1990) 'The Romance of Resistance: Tracing Transformations of

Power through Bedouin Women', American Ethnologist 17: 41-55.

Ahearn, Laura (2001) 'Language and Agency', Annual Review of Anthropology 30: 10937.

Ashforth, Adam (2005) Witchcraft, Violence, and Democracy in South Africa. Chicago:

University of Chicago Press.

Bähre, Erik (2007) 'Reluctant Solidarity: Death, Urban Poverty and Neighbourly Assistance in South Africa', Ethnography 8(1): 33-59.

Biehl, João (2005) Vita: Life in a Zone of Social Abandonment. Berkeley: University of California Press.

Biehl, João (2007) 'Pharmaceuticalization: AIDS Treatment and Global Health Politics', Anthropological Quarterly 80(4): 1083-1126.

Bloch, Maurice (1971) Placing the Dead: Tombs, Ancestral Villages and Kinship Organization in Madagascar. London: Seminar Press. 
Bloch, Maurice and Jonathan Parry (1982) 'Introduction: Death and the Regeneration of Life', in Maurice Bloch and Jonathan Parry (eds) Death and the Regeneration of Life, pp. 1-44. Cambridge: Cambridge University Press.

Bolton, Ralph and Merrill Singer (eds) (1992) Rethinking AIDS Prevention: Cultural Approaches. Philadelphia: Gordon Breach.

Bourdieu, Pierre (1977) Outline of a Theory of Practice. Cambridge: Cambridge University Press.

Brain, James (1973) 'Ancestors as Elders in Africa: Further Thoughts', Africa 43(2): 12223.

Castells, Manuel (1997) The Power of Identity. Oxford: Blackwell.

Comaroff, Jean and John Comaroff(eds) (1993) Modernity and its Malcontents: Ritual and Power in Postcolonial Africa. Chicago: University of Chicago Press.

Davidson, Donald (1980 [1971]) 'Agency', in Donald Davidson (ed) Essays on Actions and Events, pp. 43-61. Oxford: Clarendon Press. 
Dilger, Hansjörg (2008) “"We Are All Going to Die”: Kinship, Belonging, and the Morality of HIV/AIDS-Related Illnesses and Deaths in Rural Tanzania', Anthropological Quarterly 81(1): 207-32.

Englund, Harri (2006) Prisoners of Freedom: Human Rights and the African Poor. Berkeley: University of California Press.

Farmer, Paul (1992) AIDS and Accusation: Haiti and the Geography of Blame. Berkeley: University of California Press.

Farmer, Paul, Margaret Connors and Janie Simmons (eds) (1996) Women, Poverty and AIDS: Sex, Drugs and Structural Violence. Monroe, Maine: Common Courage.

Fassin, Didier (2007) When Bodies Remember: Experiences and Politics of AIDS in South Africa. Berkeley: University of California Press.

Fassin, Didier, Frédéric le Marcis and Todd Lethata (2008) 'Life and Times of Magda A.: Telling a Story of Violence in South Africa', Current Anthropology 49(2): 225-46.

Fortes, Meyer (1976) ‘An Introductory Commentary’, in William H. Newell (ed) Ancestors, pp. 1-16. The Hague: Mouton. 
Geschiere, Peter (1997) The Modernity of Witchcraft: Politics and the Occult in Postcolonial Africa. Charlottesville: University Press of Virginia.

Goffman, Erving (1997 [1961]) 'From “The Moral Career of the Mental Patient”, in Charles Lemert and Ann Branaman (eds) The Goffman Reader, pp. 63-71. Malden, MA: Blackwell.

Goody, Jack (1962) Death, Property and the Ancestors: A Study of the Mortuary Customs of the LoDagaa of West Africa. Stanford: Stanford University Press.

Hunter, Mark (2005) 'Cultural Politics and Masculinities: Multiple-partners in Historical Perspective in KwaZulu-Natal', Culture, Health \& Sexuality 7(3): 209-23.

Jindra, Michael (2005) 'Christianity and the Proliferation of Ancestors: Changes in Hierarchy and Mortuary Ritual in the Cameroon Grassfields', Africa 75(3): 356-77.

Keane, Webb (2007) Christian Moderns: Freedom and Fetish in the Mission Encounter. Berkeley: University of California Press.

Kopytoff, Igor (1971) 'Ancestors as Elders in Africa', Africa 41(2): 129-42.

Lockhart, Chris (2008) 'The Life and Death of a Street Boy in East Africa: Everyday Violence in the Time of AIDS', Medical Anthropology Quarterly 22(1): 94-115. 
McNeill, Fraser (2009) “"Condoms Cause AIDS”: Poison, Prevention and Denial in Venda, South Africa', African Affairs 108: 353-70.

Mahmood, Saba (2005) Politics of Piety: The Islamic Revival and the Feminist Subject. Princeton: Princeton University Press.

Mbembe, Achille (2004) 'Aesthetics of Superfluity', Public Culture 16(3): 373-405.

Moore, Henrietta and Todd Sanders (2001) 'Magical Interpretations and Material Realities: An Introduction', in Henrietta Moore and Todd Sanders (eds) Magical Interpretations, Material Realities: Modernity, Witchcraft and the Occult in Postcolonial Africa, pp. 1-27. London: Routledge.

Niehaus, Isak (with Gunvor Jonsson) (2005) 'Dr. Wouter Basson, Americans, and Wild Beasts: Men's Conspiracy Theories of HIV/AIDS in the South African Lowveld', Medical Anthropology 24: 179-208.

Niehaus, Isak (2006) 'Biographical Lessons: Life Stories, Sex, and Culture in Bushbuckridge, South Africa', Cahiers d'Etudes Africaines 181: 51-73.

Niehaus, Isak (2007) 'Death Before Dying: Understanding AIDS Stigma in the South African Lowveld', Journal of Southern African Studies 33(4): 845-60. 
Ortner, Sherry (1984) 'Theory in Anthropology since the Sixties', Comparative Studies in Society and History 26(1): 126-66.

Ortner, Sherry (1995) 'Resistance and the Problem of Ethnographic Refusal', Comparative Studies in Society and History 37(1): 173-93.

Ortner, Sherry (2005) 'Subjectivity and Cultural Critique', Anthropological Theory 5: 3152.

Parker, Richard (2001) 'Sexuality, Culture, and Power in HIV/AIDS Research', Annual Review of Anthropology 30: 163-79.

Posel, Deborah (2005) 'Sex, Death and the Fate of the Nation: Reflections on the Politicization of Sexuality in Post-apartheid South Africa', Africa 75(2): 125-53.

Rasmussen, Susan (2000) 'Alms, Elders, and Ancestors: The Spirit of the Gift among the Tuareg', Ethnology 39(1): 15-38.

Rasmussen, Susan (2004) 'Reflections on Witchcraft, Danger, and Modernity among the Tuareg', Africa 74(3): 315-340. 
Roberts, Sandra Jane (2005) Resisting Stigma: Living Positively with HIV/AIDS in South Africa. Unpublished MA Thesis, Department of Sociology, University of Johannesburg.

Robins, Steven (2008) From Revolution to Rights in South Africa: Social Movements, NGOs \& Popular Politics After Apartheid. Woodbridge: James Currey.

Robins, Steven (2009) 'Foot Soldiers of Global Health: Teaching and Preaching AIDS Science and Modern Medicine on the Frontline', Medical Anthropology 28(1): 81-107.

Rosaldo, Renato (1989) Culture and Truth: The Remaking of Social Analysis. Boston: Beacon Press.

Scheper-Hughes, Nancy (1992) Death Without Weeping: The Violence of Everyday Life in Brazil. Berkeley: University of California Press.

Setel, Philip (1999) A Plague of Paradoxes: AIDS, Culture and Demography in Northern Tanzania. Chicago: University of Chicago Press.

Sharp, John (2008) “'Fortress SA”: Xenophobic Violence in South Africa', Anthropology Today 24(4): 1-3.

Singer, Merrill (ed) (1998) The Political Economy of AIDS. Amityville, NY: Baywood. 
Steadman, Lyle, Craig Palmer and Christopher Tilley (1996) 'The Universality of Ancestor Worship', Ethnology 35(1): 63-76.

Stein, Jo, Tayla Soskolne and Kerry Gibson (2003) 'Working with Ambivalence: Finding a Positive Identity for HIV/AIDS in South Africa', Centre for Social Science Research Working Paper 53. Cape Town: Centre for Social Science Research.

Straight, Bilinda (2006) 'Becoming Dead: The Entangled Agencies of the Dearly Departed', Anthropology and Humanism 31(2): 101-10.

Taylor, Charles (1985) 'What Is Human Agency?', in Human Action and Agency: Philosophical Papers I, pp. 15-44. Cambridge: Cambridge University Press.

Thomas, Felicity (2007) “"Our Families are Killing Us”: HIV/AIDS, Witchcraft and Social Tensions in the Caprivi Region, Namibia', Anthropology and Medicine 14: 279-91.

Thomas, Felicity (2008) 'Indigenous Narratives of HIV/AIDS: Morality and Blame in a Time of Change', Medical Anthropology 27(3): 227-56.

Thornton, Robert (2008) Unimagined Community: Sex, Networks, and AIDS in Uganda and South Africa. Berkeley: University of California Press. 
Treichler, Paula (1999) How to Have Theory in an Epidemic: Cultural Chronicles of AIDS. Durham, NC: Duke University Press.

Wardlow, Holly (2006) Wayward Women: Sexuality and Agency in a New Guinea Society. Berkeley: University of California Press.

Weir, Jennifer (2005) ‘Whose uNkulunkulu?', Africa 75(2): 203-19.

Wojcicki, Janet Maia (2002) “'She Drank His Money”: Survival, Sex and the Problem of Violence in Taverns in Gauteng Province, South Africa', Medical Anthropology Quarterly 16(3): 267-93.

\section{BIO}

Mieke deGelder is a SSHRC Postdoctoral Fellow at the Institute for Women's and Gender Studies, University of Pretoria. She received her $\mathrm{PhD}$ in anthropology from the University of Toronto in 2011. Her doctoral research focused on urban transformation in Tshwane (inner city Pretoria and surrounding townships), South Africa, and considered in particular one locally-initiated NGO's attempt to create a 'moral community' in the postapartheid city. For her current research project she is examining the reconstitution of South Africa's 'poor whites' as particular racialized, classed and gendered subjects in the post-apartheid state. Address: Institute for Women's and Gender Studies, Human Sciences Building Room 20-17.2, University of Pretoria, Pretoria 0002, South Africa. [email: degelder.m@gmail.com] 


\section{ACKNOWLEDGEMENTS}

I am grateful to Sheri Gibbings, Michael Lambek, Sharon Roseman, Todd Sanders and the anonymous reviewers of Ethnography for their very helpful comments and suggestions on earlier versions of this article. The research on which this article is based was generously supported by a Dissertation Fieldwork Grant from the Wenner-Gren Foundation and a Canada Graduate Scholarship from the Social Sciences and Humanities Research Council of Canada. 